\title{
Effects of the pH on growth and morphology of Anabaenopsis elenkinii MILLER (Cyanobacteria) isolated from the alkaline shallow lake of the Brazilian Pantanal
}

\author{
Kleber Renan de Souza Santos, Fernanda Rios Jacinavicius \& Célia Leite \\ SANT'ANNA
}

Laboratory of Phycology, Institute of Botany, Av. Miguel Estéfano 3687, CEP 04301-902, São Paulo-SP, Brazil; e-mail: santoskrs@gmail.com

\begin{abstract}
Anabaenopsis elenkinii Miller forms bloom in the alkaline shallow lakes of the Brazilian Pantanal. The A. elenkinii CCIBT1059 strain was isolated from one of these alkaline lakes and the experiments were made in growth chamber during 30 days, under modified medium $\mathrm{BG}-11\left(3 \% \mathrm{NaNO}_{3}\right)$, temperature $25{ }^{\circ} \mathrm{C}$, photoperiod 12-12 light-dark cycle and irradiance of $80-100 \mu \mathrm{mol}$ photons $\mathrm{m}^{-2} \mathrm{~s}^{-1}$ at three different $\mathrm{pH}$ values: $7.0,9.5$ and 10.5. In relation to growth rate and cell yield the higher values were observed at $\mathrm{pH} 10.5$. Morphologically, the longest trichomes were found at $\mathrm{pH} 7$ (maximum 45 cells) in comparison with $\mathrm{pH} 9.5$ (maximum 32 cells) and pH 10.5 (maximum 23 cells). The occurrence of heterocytes was observed in all treatments, but akinetes were never formed. The morphometric variability within each treatment between exponential and stationary growth was clearly higher than the variability among different treatments in most cases. Our results indicate that $A$. elenkinii is typical of alkaline systems and also that in lower $\mathrm{pH}$ values the growth limitation can occur in terms of number of cells and biomass. This study represents the first experimental evidence of the effects of $\mathrm{pH}$ on growth rate, cell yield and morphometric variability of $A$. elenkinii.
\end{abstract}

Key words: alkaline lakes, Anabaenopsis elenkinii, Brazilian Pantanal, Cyanobacteria, pH, wetland

\section{Introduction}

The Pantanal is a large wetland of about 160,000 $\mathrm{km}^{2}$ located in the center of the South American continent (JunK et al. 2006). The Brazilian Pantanal is divided into eleven sub-regions that are characterized by the relief, soil, vegetation and flood pulse (Silva \& ABdon 1998). The studied sub-region, Pantanal of Nhecolândia, displays hundreds of typical and exclusive shallow lakes with high $\mathrm{pH}$ values ( $>9)$. Therefore, these lakes can be considered as extreme environments for most life forms (KRISTJÁNSSON \& HREGGVIDSSON 1995). These alkaline lakes were isolated from rivers or streams and the main source of water is rainfall and groundwater (BARBIÉRO et al. 2002). In the alkaline lakes there are no macrophytes or fish and the dominant organisms are cyanobacteria (SANTOS \& SANT'AnNA 2010).

The high values of $\mathrm{pH}$, electric conducti- vity, nutrients concentrations, cyanobacteria density and the lack of fish in the alkaline lakes from Pantanal of Nhecolândia are comparable to those of shallow lakes from arid regions of Australia (Hart et al. 1991), Nigeria (EgBorge 1994), Ethiopia (TUdORANCEA \& HARRINSON 1988) and Africa (BALlot et al. 2008).

In these Brazilian extreme lakes, Anabaenopsis elenkinii Miller is the dominant organism and forms blooms (Fig. $1 \mathrm{a}, \mathrm{b}$ ), mainly in the dry season (SANTOS \& SANT'AnNa 2010).

In spite of being the dominant species in the alkaline lakes from the Pantanal and potentially toxic (CARvalho et al. 2008), A. elenkinii is still little known in terms of development. Thus, our objective is to investigate the effects of $\mathrm{pH}$ on growth and morphology of $A$. elenkinii CCIBT1059, isolated from Brazilian Pantanal. 
Table 1. Growth rate, duplication time and cell yield of the Anabaenopsis elenkinii strain CCIBT1059, in the exponential growth at different treatment of $\mathrm{pH}$. The cultures were incubated at $25^{\circ} \mathrm{C}$, irradiance of $80-100 \mu \mathrm{mol}$ photons. $\mathrm{m}^{-2} \cdot \mathrm{s}^{-1}$ on a $12-12$ hr light-dark cycle on modified medium BG-11 $\left(3 \% \mathrm{NaNO}_{3}\right)$. Different letters after the date indicate significant differences at $p<0.05(n=3)$.

\begin{tabular}{ccccc}
\hline & $\begin{array}{c}\text { Exponential } \\
\text { growth } \\
\text { (day) }\end{array}$ & $\begin{array}{c}\text { Growth rate } \\
\left(\mu ; \text { day }^{-1}\right)\end{array}$ & $\begin{array}{c}\text { Duplication } \\
\text { time } \\
\left(\mathrm{G} ; \text { day }^{-1}\right)\end{array}$ & $\begin{array}{c}\text { Cell yield } \\
(\mathrm{R} ; \text { cells.ml }\end{array}$
\end{tabular}

\section{Materials and Methods}

The studied nonaxenic strain CCIBT1059 is kept in modified liquid medium BG-11 (3\% $\mathrm{NaNO}_{3}$, indicated as BG-11m), $\mathrm{pH} 9.5$, temperature $23 \pm 1{ }^{\circ} \mathrm{C}$, photoperiod 14-10 light-dark cycle and irradiance of 40-50 $\mu \mathrm{mol}$ photons. $\mathrm{m}^{-2} \cdot \mathrm{s}^{-1}$ (provided by common day light fluorescent lamps and measured with a quanta meter sensor Li-COR model LI-250 spherical) in the Cyanobacteria Culture Collection of Institute of Botany, São Paulo, Brazil. If was isolated from the alkaline shallow lake named "Salina do Meio" (18 $58^{\circ} 29$ " S and $56^{\circ} 38^{\prime} 47^{\prime \prime} \mathrm{W}$ ), State of Mato Grosso do Sul, Brazilian Pantanal.

The morphological and metric $(n=200)$ characterization of material from nature and from culture were done under light microscope (Zeiss Axioplan 2). The classification system of HoFFMANN et. al. (2005) and taxonomic review of KomÁREK (2005) were adopted.

At the end of the exponential phase, one aliquot of the strain CCIBT1059 was taken and incubated over ten days in the growth chamber under the following conditions: $\mathrm{BG}-11 \mathrm{~m}, \mathrm{pH} 9.5$, temperature $25{ }^{\circ} \mathrm{C}$, photoperiod 12-12 light-dark cycle and irradiance of 80-100 $\mu \mathrm{mol}$ photons. $\mathrm{m}^{-2} \cdot \mathrm{s}^{-1}$. This adapted culture was used as inoculums for the $\mathrm{pH}$ treatments, initiated with $1.5 \times 10^{4}$ cells. $\mathrm{ml}^{-1}$. Cells were inoculated into 11 glass balloons with $500 \mathrm{ml}$ of medium BG-11m. The $\mathrm{pH}$ was adjusted varying the amount of $\mathrm{NaOH} 0.1 \mathrm{M}$ and $\mathrm{HCl} 0.1 \mathrm{M}$ in the medium. The treatments $(n=3)$ were the following: $\mathrm{pH} 7.0,9.5$ and 10.5.

During 30 days, daily analyses in FuchsRosenthal counting chamber were performed for determining the growth (cells.ml ${ }^{-1}$ ) and biovolume $\left(\mathrm{mm}^{3} \cdot \mathrm{l}^{-1}\right)$ for every treatment. Growth rates were calculated during the exponential phase and are presented as relative growth rate $\left(\mu\right.$, day $\left.^{-1}\right)$. Mean doubling time represents the time period necessary to duplicate the cell population $\left(\mathrm{G}\right.$, day $\left.^{-1}\right)$, both estimated according to FogG \& THAKE (1987). The cell yield (R; cells. $\mathrm{ml}^{-1}$ ), corresponding the maximum number of cells subtracted of the cell number of the inoculums, was also calculated.
All treatments were analyzed using the analysis of variance (ANOVA) and Tukey test (Program GraphPad Prism version 5.0). Results of all tests were considered significant at $95 \%$ confidence if $p<0.05$ for a given $F$ statistic test value.

\section{Results}

\section{Morphological characteristics of $\boldsymbol{A}$. elenkinii}

The following morphometric parameters, observed during the exponential growth of all treatments (Fig. 2, Supplementary Table 1. - electronic version only at fottea.czechphycology.cz), showed significant differences when compared with nature material: lower values of cell length in the treatments, higher values of cell width in the treatments, lower values of cell length/width ratio in the treatments, and higher values of length and width of heterocytes and number of cells in trichomes were also observed in the treatments ( $p$ $<0.0001)$. Regarding the number of coils, more tightly coiled trichomes were observed only at $\mathrm{pH} 10.5$ in comparison with nature material $(p<$ $0.0001)$.

During the stationary growth (Fig. 2), significant differences were observed in all treatments when compared with nature material in the following parameters: lower values of length and width of cells were observed in all treatments ( $p<0.0001$ ) and number of cells in trichome as well as length and width of heterocytes showed higher values in treatments $(p<0.0001)$. Regarding the length/width ratio of cells, significant difference were observed at $\mathrm{pH} 9.5(p<0.0001)$ and $10.5(p$ $<0.003$ ) and lower values were observed in these treatments. Furthermore, the length/width ratio of heterocytes higher values were observed at $\mathrm{pH}$ $7.0(p<0.003)$ and $9.5(p<0.0001)$. As with the exponential growth, more tightly coiled trichomes 

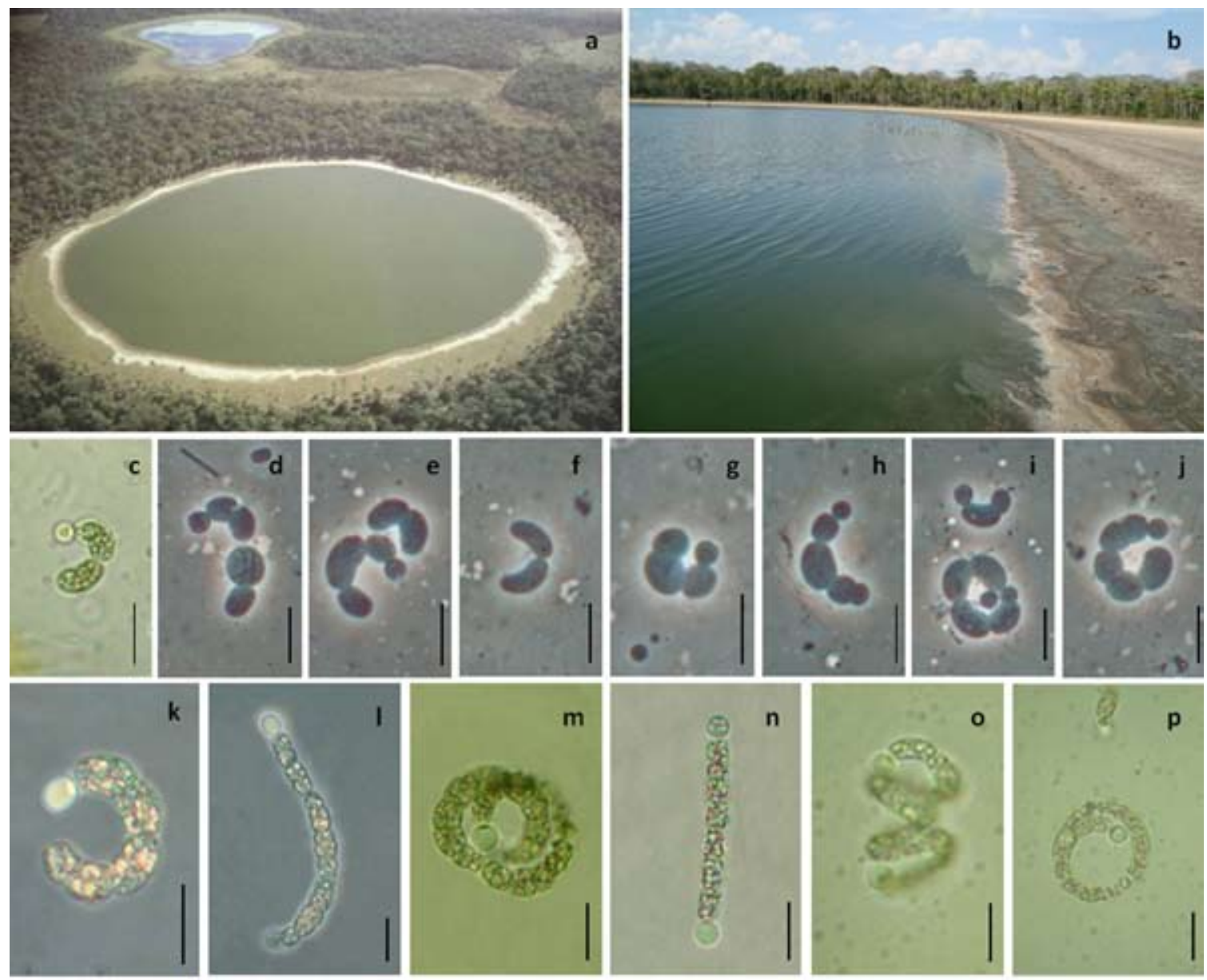

.
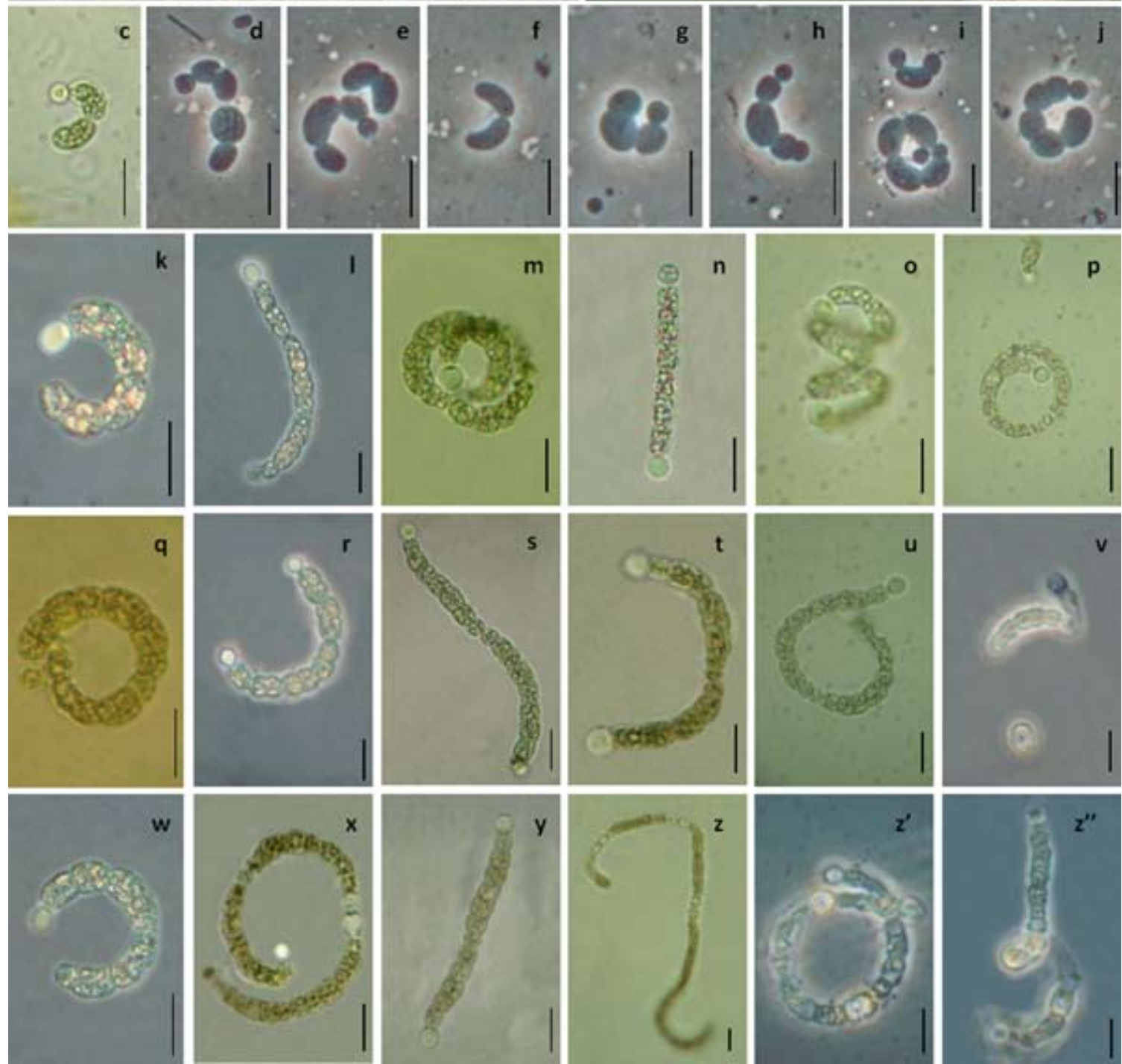

Fig. 1. Aspects of alkaline lake and species studied: (a) general view of the lake "Salina do Meio"- photo A. Pott; (b) occurrence of bloom of the Anabaenopsis elenkinii in lake; (c-z") A. elenkinii; (c-j) nature material; (k-z") strain CCIBT1059; (k-p) pH 10.5 on day $0,7,10,14,20$ and 30 respectively; (q-v) pH 9.5 on day $0,4,10,14,20$ and 30 respectively; (w-z") pH 7.0 on day $0,8,10,14,20$ and 30 respectively. Scale bar $10 \mu \mathrm{m}$. 

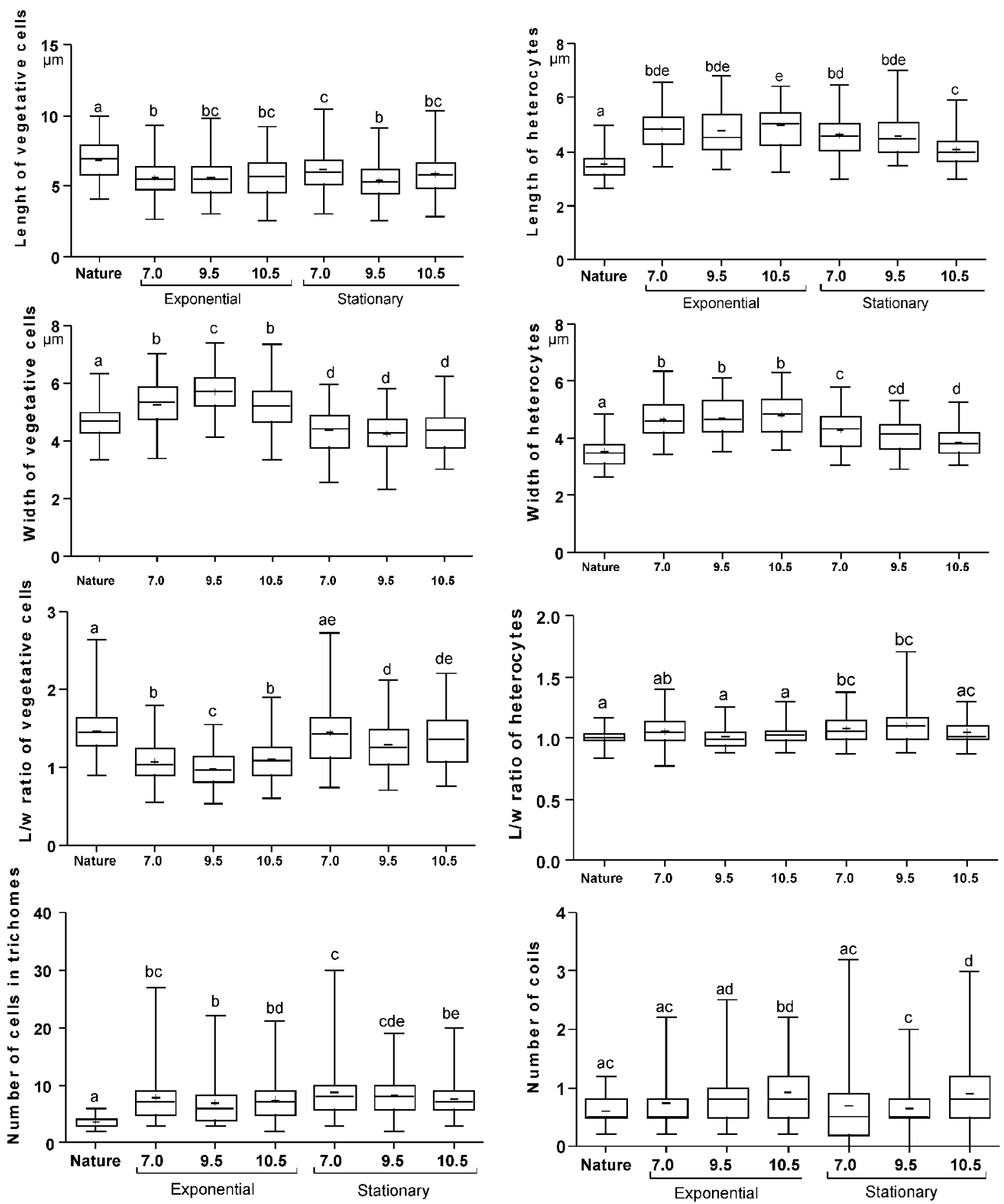

Fig. 2. Box and whisker plots of morphological characteristics of Anabaenopsis elenkinii strain CCIBT1059 in the nature material and exponential and stationary growth at different treatment of $\mathrm{pH}$. Whiskers represent minimum and maximum values, boxes symbolize \pm standard deviation, and "+" inside boxes are mean values. $\mathrm{L} / \mathrm{w}=$ length/width.

$(p<0.0001)$ were observed only at $\mathrm{pH} 10.5$ on stationary growth in comparison with nature material (Fig. 2).

According to figure 2 , the variability within each treatment between exponential and stationary growth was clearly higher than the variability among different treatments in most cases. Regarding the length of cells, statistical differences were observed only at $\mathrm{pH} 7.0$, in which higher values were encountered at stationary growth. The length of heterocytes showed statistical difference only at $\mathrm{pH} 10.5$ and lower values were observed at 

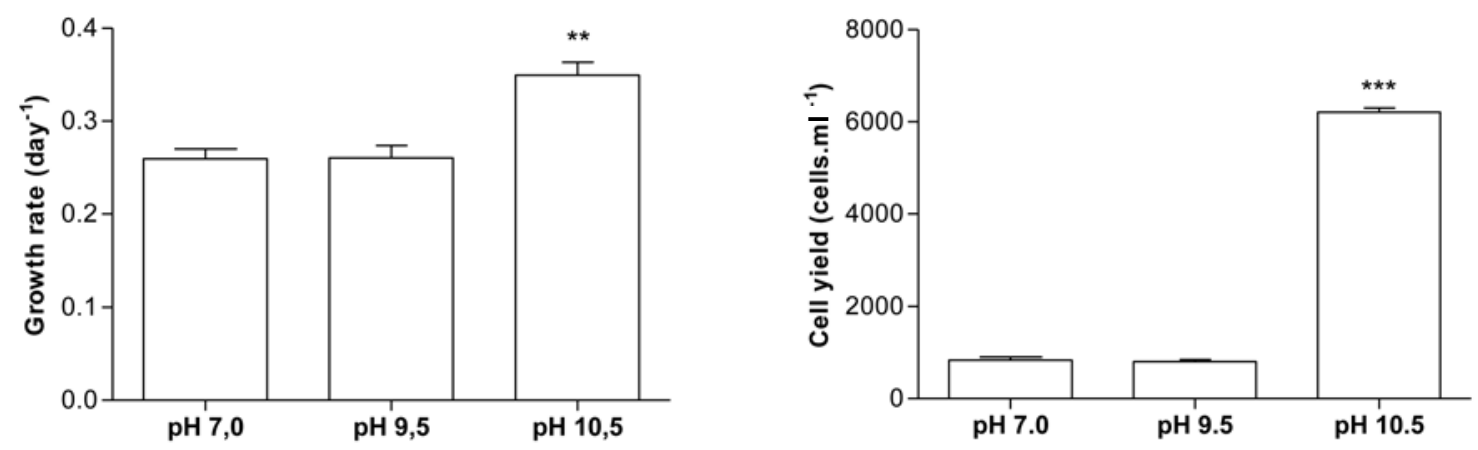

Fig. 3. Growth rate and cell yield of Anabaenopsis elenkinii strain CCIBT1059 on exponential growth at different treatment of $\mathrm{pH}$. The cultures were incubated at $25^{\circ} \mathrm{C}$, irradiance of $80-100 \mu \mathrm{mol}$ photons. $\mathrm{m}^{-2} \cdot \mathrm{s}^{-1}$ on a $12-12 \mathrm{hr}$ light-dark cycle on modified medium $\mathrm{BG}-11\left(3 \% \mathrm{NaNO}_{3}\right)$. Error bars denote the standard deviation $(n=3)$. Asterisks above the bars indicate significant differences at $p<0.05$.

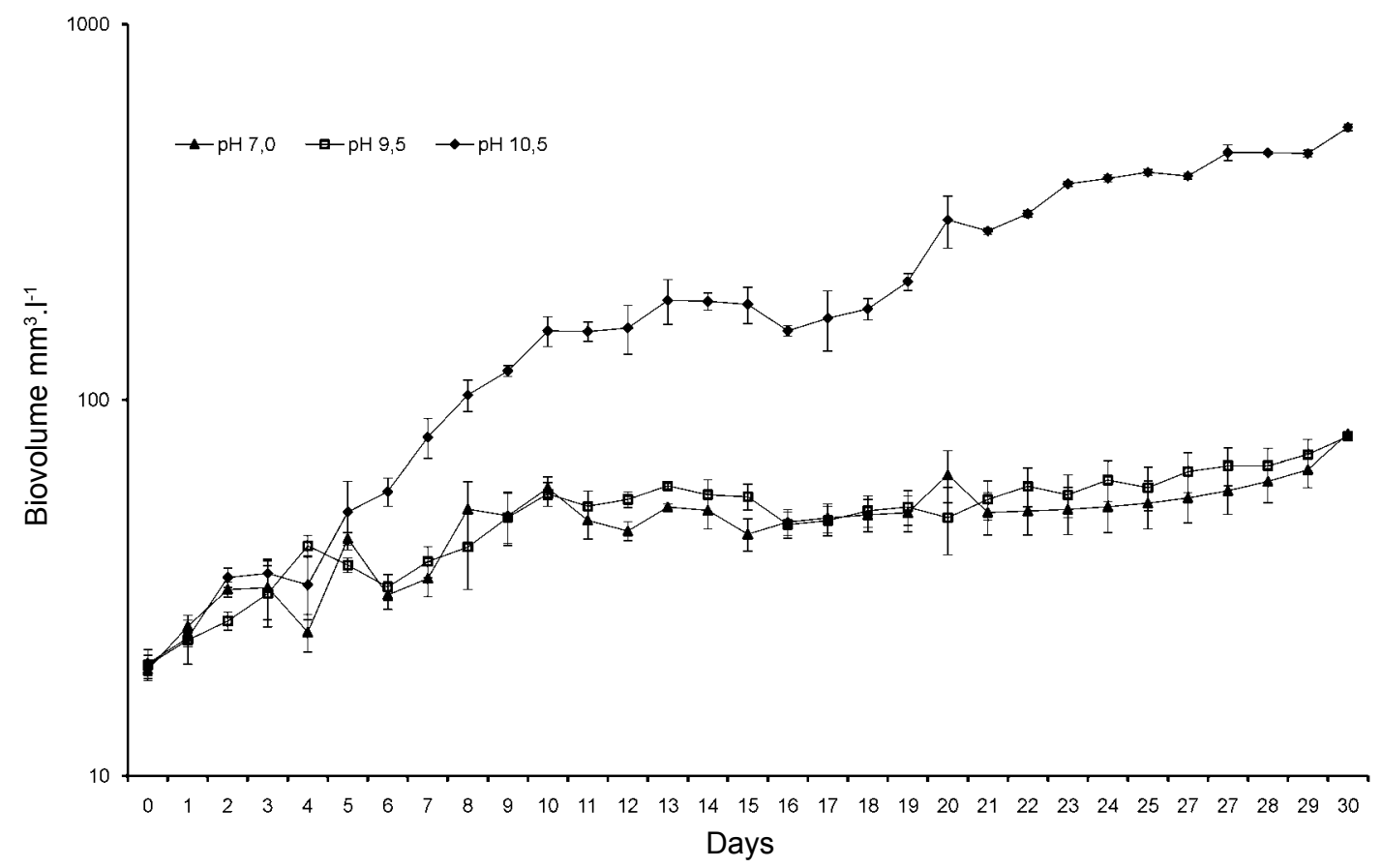

Fig. 4. The growth curves (Biovolume $\mathrm{mm}^{3} . \mathrm{l}^{-1}$ ) of Anabaenopsis elenkinii strain CCIBT1059 at different $\mathrm{pH}$ treatments. The cultures were incubated at $25^{\circ} \mathrm{C}$, irradiance of $90 \mu \mathrm{mol}$ photons. $\mathrm{m}^{-2} \cdot \mathrm{s}^{-1}$ on a $12-12 \mathrm{hr}$ light-dark cycle on modified medium BG-11 $\left(3 \% \mathrm{NaNO}_{3}\right)$. Error bars indicate the standand deviation $(n=3)$.

stationary growth $(p<0.05)$. However, the width of cells and heterocytes showed lower values at stationary growth in comparison with exponential growth at $\mathrm{pH} 7.0,9.5$ and 10.5. The number of cells and coils per trichomes and the length/width ratio of heterocytes showed statistical difference between both phases of growth only at $\mathrm{pH} 9.5$, in which slightly coiled trichomes were observed on exponential growth, whereas a higher number of cells per trichome and heterocytes slightly longer were encountered on stationary growth (Fig. 2, Supplementary Table 2 - electronic version only at fottea.czechphycology.cz). In nature material and in all treatments, the coiled trichomes were the dominant form, but in each treatment a small percentage of straight trichomes were observed at stationary growth (Fig. $1 \mathrm{c}-\mathrm{x}$ ).

The longest trichomes were found at $\mathrm{pH}$ 7 (maximum 45 cells on day 14) in comparison with pH 9.5 (maximum 32 cells on day 10) and 
pH 10.5 (maximum 23 cells on day 8). Although statistical analyses showed significant difference in the number of cells per trichomes, the real difference in the mean values was slight (ca. 1 cell). Moreover, the average during the cultivation time (30 days) was approximately 8 cells per trichome in all treatments (Suppl. Tables 1,2).

\section{Growth of $A$. elenkinii}

The effect of different $\mathrm{pH}$ on growth rate $\left(\mu ;\right.$ day $\left.^{-1}\right)$, cell yield (R; cells.ml $\left.{ }^{-1}\right)$ and duplication time $(\mathrm{G}$; day $^{-1}$ ) of the $A$. elenkinii strain CCIBT1059 are shown in Fig. 3 and Table 1. Higher values of growth rate and cell yield were observed at $\mathrm{pH} 10.5$ and were statistically different from $\mathrm{pH} 7\left(p_{[\mu]}<\right.$ $0.05 ; p_{[\mathrm{R}]}^{<0.0001)}$ and $9.5\left(p_{[\mu]}<0.05 ; p_{[\mathrm{R}]}^{<}\right.$ 0.0001 ). Consequently, the duplication time of cells was lower at $\mathrm{pH} 10.5$ and higher at $\mathrm{pH} 7$ and 9.5 (Table 1). In $\mathrm{pH} 7$ and in $\mathrm{pH} 9.5$ were not observed statistically difference in relation to growth rate, cell yield and duplication time of cells.

Figure 4 shows the growth curves (biovolume $\mathrm{mm}^{3} . \mathrm{l}^{-1}$ ) of $A$. elenkinii at different treatments of $\mathrm{pH}$.

\section{Discussion}

Morphologically, the nature material of $A$. elenkinii is similar to that of Anabaenopsis hungarica Halász because of the small number of cells/ trichome (average 4, varying from 2 to 6 cells) and by the cylindrical cells (Fig. 1, c-j). However, the Brazilian material frequently presents longer trichomes (up to12 cells) and elliptical cells (SAntos \& SAnt'Anna 2010). Besides, the metric parameters are also very distinct: $A$. hungarica presents $2.5 \mu \mathrm{m}$ wide trichomes and the $A$. elenkinii trichomes are wider $(4.5 \mu \mathrm{m})$ (KOMÁREK 2005). According to morphometric parameters, the material from Pantanal (from nature and from culture) is similar to A. elenkinii and the variability observed was considered as part of the natural variability of this species (KOMÁREK 2005, SANTOS $\&$ SANT'ANNA 2010).

The occurrence of terminal and intercalary pairs of heterocytes was observed in all treatments (Fig. $1 \mathrm{k}-\mathrm{z}$ "), but akinetes were never formed during the cultivation time. Based on our results, the occurrence of heterocytes was proportionally equal to the density of trichomes in all treatments (not shown), indicating that the $\mathrm{pH}$ does not affect the heterocyte formation.

Akinetes were found only in nature, where they appeared during the dry season of the years 2006 and 2009 (pH 9.5-9.9 and water temperature $\left.25-32{ }^{\circ} \mathrm{C}\right)$ and on the rain season of $2006(\mathrm{pH}$ 10.2 and water temperature $33{ }^{\circ} \mathrm{C}$ ) (SANTOS \& SANT'ANnA 2010). The absence of akinetes in the analyzed treatments indicates that the tested culture conditions do not represent stress conditions that induce the production of resistance structures. For this reason, in spite of the lower growth rate at $\mathrm{pH}$ 7.0 and 9.5 (Table 1) compared with the literature (growth rates of 0.3-1.4, according to MuR et al. 1999), akinetes were never formed. Although the influence of $\mathrm{pH}$ on akinetes sporulation has been documented for Anabaenopsis arnoldii APTEKAR by REDDY (1984), our results indicate that $\mathrm{pH}$ does not seem to be directly involved in akinetes formation of $A$. elenkinii from the alkaline lakes of Pantanal. Environmental features such as temperature (SHAFIK et al. 2003; Moore et al. 2004), phosphorus concentration (MOORE et al. 2004) and light intensity (Moore et al. 2005) showed great influence on akinetes formation of Cylindrospermopsis raciborskii (WoLOSZYŃSKA) Seenayya et Subba Raju. However, Zapomělová et al. (2008) studied the effects of the temperature, light intensity and nutrient composition on morphological traits of Nostocaceae (Anabaena, Aphanizomenon, Nostoc, Scytonema and Tolypothrix), but did not manage to prove the influence of these parameters on the akinetes formation.

In all treatments, $A$. elenkinii strain CCIBT1059 showed tendency to decrease the cell width at the stationary growth compared with that at the exponential growth (Fig. 2). The same observation was documented to $C$. raciborskii (HAwKIns et al. 2001). The length/width ratio of cells tends to increase during the cultivation time because the cell width decreases independently of $\mathrm{pH}$.

AccordingtoHarRIS(1986), phytoplanktonic cells with high growth rate tend to have a smaller cell volume. In spite of no significant difference on the growth of $A$. elenkinii between the treatment at $\mathrm{pH} 7$ and that at $\mathrm{pH} 9.5$, variability of the width and length/width ratio of cells was observed. Treatment at $\mathrm{pH} 9.5$ presented shorter cells than that at $\mathrm{pH}$ 7.0, both in the exponential growth phase and at the stationary phase (Fig. 2). Another interesting aspect observed was the morphological similarity of the trichomes between the treatment at $\mathrm{pH} 7.0$ 
and that at $\mathrm{pH} 10.5$ during the exponential growth, except for the number of coils/trichome (Fig. 2).

The higher values of growth rate and cell yield observed at $\mathrm{pH} 10.5$ indicate that $A$. elenkinii is typical of alkaline systems and also that in lower $\mathrm{pH}$ values the growth limitation can occur in terms of density and biomass (Table 1). Thus, the bloom formation of $A$. elenkinii in the alkaline lakes from Brazilian Pantanal is favored by the high $\mathrm{pH}$ values towards its high productivity.

\section{Acknowledgements}

The first author thanks the financial supports of Fundação de Amparo à Pesquisa do Estado de São Paulo (FAPESP - Process number 2009/51655-1). We also thank the Embrapa Pantanal for permission to collect phytoplankton samples in Nhumirim farm, and Dr. Arnaldo Yoso Sakamoto (Universidade Federal de Mato Grosso do Sul - UFMS Campus de Três Lagoas) for the logistics support for the collection expedition.

\section{References}

Ballot, A., Dadheech, P.K., HaAnde, S. \& Krienitz, L. (2008): Morphologicaland phylogeneticanalysis of Anabaenopsis abijatae and Anabaenopsis elenkinii (Nostocales, Cyanobacteria) from tropical inland water bodies. - Microb. Ecol. 55: 608-618.

Barbiéro, L., Queiroz-Neto, J.P., Ciornei, G., Sakamoto, A.Y., Capellari, B., Fernandes, E. \& VALLES, V. (2002): Geochemistry of water and ground water in the Nhecolândia, Pantanal of Mato Grosso, Brazil: variability and associated processes. - Wetland 22: 528-540.

Carvalho, L.R., Pipole, F., Werner, V.R., Laughinghouse IV, H.D., Camargo, A.C.M., Rangel, M., Konno, K. \& SAnt'Anna, C.L. (2008): A toxic cyanobacterial bloom in an urban coastal lake, Rio Grande do Sul State, Southern Brazil. - Braz. J. Microbiol. 39: 761-769.

Egborge, A.B.M. (1994): Salinity and the distribution of rotifers in the Lagos Harbour - Badagry Creek system, Nigeria. - Hydrobiologia 272: 95-104.

FogG, G.E. \& ThAKe, B. (1987): Algae cultures and phytoplankton ecology, $3^{\text {rd }}$ ed. -269 pp., Wisconsin, University Wisconsin Press, Madison.

HARris, G.P. (1986): Phytoplankton ecology: structure, function and fluctuation. - 384 pp., Chapman and Hall Press, London.

Hart, B.T., Bailey, P., Edwards, R., Hortle, K., James, K., McMahon, A., Meredith, C. \& Swadling, K. (1991). A review of the salt sensitivity of the
Australian freshwater biota. - Hydrobiologia 210: 105-144.

Hawkins, P.R.; Putt, E.; Falconer, I.; Humpage, A. (2001): Phenotipical variation in a toxic strain of the phytoplankter, Cylindrospermopsis raciborskii (Nostocales, Cyanophyceae) during batch culture. - Environ. Toxicol. 16: 460-467.

Hoffmann, L., KomÁrek, J. \& KaštovskÝ, J. (2005): System of cyanoprokaryotes cyanobacteria) state in 2004. - Algological Studies 117: 95115.

Junk, W.J., Cunha, C.N., Wantzen, K.M., Petermann, P., Strüssmann, C., Marques, M.I. \& Adis, J. (2006): Biodiversity and its conservation in the Pantanal of Mato Grosso, Brazil. - Aquat. Sci. 68: 278-309.

KomÁReK J. (2005). Phenotypic diversity of the heterocytous cyanoprokaryotic genus Anabaenopsis. - Czech Phycology 5: 1-35.

Kristú́nsson, J.K. \& Hreggvidsson, G.O. (1995): Ecology and habitats of extremophiles. - Word. J. Microbiol. Biotechnol. 11-17-25.

Moore, D., McGregor, G.B. \& Glen, S. (2004): Morphological changes during akinetes germination in Cylindrospermopsis raciborskii (Nostocales, Cyanobacteria). - J. Phycol. 40: 1098-1105.

Moore, D., O’Donohue, M., Garnett, C., Critchley, C. \& SHAw, G. (2005): Factors affecting akinete differentiation in Cylindrospermopsis raciborskii (Nostocales, Cyanobacteria). Freshwater Biol. 50: 345-352.

Mur, L.R., Skulberg, O.M. \& Utkilen, H. (1999): Cyanobacteria in the environment. - In: Chorus, I. \& Bartram, J. (eds): Toxic cyanobacteria in water. A guide to their Public Health Consequences, Monitoring and Management. 416 pp., E \& FN Spon, London \& New York.

Reddy, P.M. (1984): Influence of $\mathrm{pH}$ on sporulation, spore germination and germling survival in blue-green algae. - Acta Hydrochim. Hydrobiol. 12: 411-417.

Shafik, H.M., Vörös, L., Spróber, P., Présing, M. \& KovÁcs, A.W. (2003): Some special morphological features of Cylindrospermopsis raciborskii in batch and continuous cultures. Hydrobiologia 506-509: 163-167.

SAntos, K.R.S. \& SAnT'AnNA, C.L. (2010): Cianobactérias de diferentes tipos de lagoas ("salina", "salitrada" e "baía") representativas do Pantanal da Nhecolândia, MS, Brasil. Revista Brasil. Bot. 33: 61-83.

Silva, J.S.V. \& Abdon, M.M. (1998): Delimitação do Pantanal brasileiro e suas sub-regiões. Pesquisa Agropecuária Brasileira 33: 17031711.

Tudorancea, C. \& Harrinson, A.D. (1988): The benthic communities of the saline lakes Abijata 
and Shala (Ethiopia). - Hydrobiologia 197:

91-97.

ZAPOMĚLovÁ, E., HrouZeK, P., ŘehÁKovÁ, K., ŠSABACKÁ, M., Stibal, M., Caisová, L., Komárková, J. \& LUKEŠOvÁ, A. (2008): Morphological variability in selected heterocystous cyanobacterial strains as a response to varied temperature, light intensity and medium composition. - Folia Microbiol. 53: 333-341.

(C) Czech Phycological Society (2011)

Recieved Sept 2010

Accepted Dec 2010 